\title{
Быченкова Ю.В.
}

\section{О формировании межкультурной компетенции у студентов вуза в системе непрерывного образования}

\author{
Bychenkova Yu.V. \\ Developing university students' intercultural competence \\ in the system of life-learning education
}

Статья посвящена рассмотрению актуальности и степени разработанности вопроса о формировании межкультурной компетенции у студентов-переводчиков, обучающихся по программе профессиональной переподготовки. Анализируется педагогическая литература $и$ официальные документы по исследуемой проблеме Ключевые слова: поликультурное образование, межкультурная компетенция, профессиональная переподготовка, непрерывное образование

Быченкова Юлия Владимировна

Магистрант

Рязанский государственный университет им. С.A. Есенина

г. Рязань, ул. Свободы, 46
The article dwells upon the importance of the question of the intercultural competence development in the students-interpreters enrolled on a program of professional retraining. You can find here the analysis of the pedagogical literature and official documents on the problem discussed

Key words: polyticultural education, intercultural competence, professional retraining, life-long education

\section{Bychenkova Yuliia Vladimirovna}

Master

Ryazan state university named S.A. Yesenin

Ryazan, Svobody st., 46

В условиях существующего нового мультиполярного мира поликультурность становится неотъемлемой частью и характеристикой современного порядка, а поликультурное образование - важнейшей составляющей процесса развития и воспитания личности. Нет сомнений в том, что полноправному гражданину информационного общества необходимо не только обладать важными и достоверными знаниями в своей профессиональной области, но и уметь применять навыки на практике, тем самым проявляя свою компетенцию.

В соответствии с требованиями развивающегося рынка труда в реалиях глобализации, каждый специалист должен постоянно повышать квалификацию, применяя в своей деятельности новые технологии работы, получая дополнительные знания, проходя программы профессиональной переподготовки. Все это приводит к концепции непрерывного образования, подразумевающей процесс роста образовательного потенциала личности в течение всей жизни, организационно обеспеченный системой государственных и обще- 
ственных институтов и соответствующий потребностям личности и общества, в настоящее время принятой повсеместно [3]. В связи с расширением географии контактов и развитием сотрудничества Российской Федерации со странами по всему миру, возрастает значимость иностранного языка как универсального и уникального связующего звена между людьми и организациями, поэтому так остро сегодня стоит вопрос о формировании межкультурной компетенции специалистов, обучающихся по программам непрерывного образования.

Цель данной статьи - показать значимость и актуальность исследования формирования межкультурной компетенции у студентов-переводчиков, обучающихся по программе профессиональной переподготовки «Переводчик в сфере профессиональной коммуникации». Методы исследования - анализ и систематизация положений педагогической литературы по данной проблеме и изучение официальных документов в области образования.

Вопросами поликультурного образования занимались многие российские ученые, такие как, например, А.Ю. Белогуров [2], И.С. Бессарабова [1], Л.Л. Супрунова [10] и многие другие. Охватывая множество важнейших аспектов, поликультурное образование рассматривается как «способ формирования лингвосоциокультурно компетентной многоязычной личности, вобравшей в себя ценности родной и иной культур и способной к адекватному, продуктивному межкультурному общению» [5, с. 89].

Становится совершенно очевидным тот факт, что нельзя в полной мере охарактеризовать программу профессиональной переподготовки «Переводчик в сфере профессиональной коммуникации», не говоря о поликультурности и смежных с ней понятиях. Поликультурность является основой функционирования данной программы, так как студенты-переводчики учатся быть «посредниками» в диалоге между культурами, содействуя развитию межкультурных связей и результативному общению.

Важность непрерывного (life-long education) и поликультурного образования подчеркивается во многих официальных документах и законодательных актах нашей страны. Так, согласно Постановлению Правительства РФ «О национальной доктрине образования в Российской Федерации» система образования призвана обеспечить: уважительное отношение к языкам, традициям и культуре других народов; развитие культуры межэтнических отношений; непрерывность образования в течение всей жизни человека [8]. Большое значение диалогу культур и бережному отношению к культурному разнообразию уделяется в Концепции духовно-нравственного развития и воспитания личности гражданина России [7]. Нельзя не отметить также Ф3 «Об образовании в Российской Федерации», в статье 76 которого говорится, что «программа профессиональной переподготовки направлена на получение компетенции, необходимой для выполнения нового вида профессиональной деятельности, приобретение новой квалификации» [11]. Особенного внимания заслуживает Постановление «О Федеральной целевой программе развития образования на 2016 -2020 годы» [9], в котором делается акцент на значении непрерывного образования для имиджа страны, развития ее потенциала. 
Рассматривая процесс формирования межкультурной компетенции у студентов-переводчиков, необходимо понять, что именно включает в себя это определение. Одним из ведущих учёных, разрабатывающих вопросы межкультурной компетенции, является британский исследователь, профессор Даремского университета М. Байрам. М. Байрам определяет межкультурную компетенцию как совокупность пяти элементов: отношения, знания, умения интерпретации и соотнесения, умения делать открытия и взаимодействовать, критическое осознание культуры/политическое образование [12].

Несомненно, тема формирования межкультурной компетенции студентов-переводчиков, обучающихся по программе профессиональной переподготовки, была и будет актуальна до тех пор, пока данная программа будет реализовываться в учреждениях высшего профессионального образования, в связи с недостаточной ее изученностью и повышенным интересом к ее исполнению. Формирование межкультурной компетенции «не завершается с окончанием обучения в вузе. Этот процесс может продолжаться на протяжении всей жизненной карьеры, и на каждом новом витке человек берет свою высоту» [6, с. 176]. Важность формирования у студентов межкультурной компетенции в обучении иностранным языкам продиктована такими происходящими в современном обществе радикальными изменениями, как результат интеграции нашей страны в мировое образовательное, информационное, экономическое пространство, побуждающий человека уметь сосуществовать в общем жизненном мире, то есть быть способным и готовым строить конструктивный диалог со всеми субъектами этого пространства [4].

Таким образом, мы можем наблюдать, как поликультурное образование органично вошло в нашу жизнь, не оставляя нам выбора, лишь позволяя смириться с мыслью, что отныне нельзя существовать в пределах одной культуры и одного языка. Будучи непосредственными участниками межкультурного взаимодействия, студенты-переводчики несут огромную ответственность за качество и продуктивность диалога между культурами. В связи с этим, процесс формирования межкультурной компетенции у студентов гуманитарного вуза, обучающихся по программе профессиональной переподготовки «Переводчик в сфере профессиональной коммуникации» требует большого внимания со стороны преподавательского состава, а исследование этого процесса имеет огромную теоретическую и практическую значимость для повышения качества подготовки переводчиков.

\section{Список используемых источников:}

1. Бессарабова И.С. Подходы к поликультурному образованию в России и США: коммуникативный аспект // Научные исследования и разработки. Современная коммуникативистика. 2013. T. 2 . № 2. C. 36-44.

2. Жукова Е.А., Белогуров А.Ю. Терминологическая и содержательная вариативность поликультурного мировоззрения и его дальнейшие тенденции // Вестник Костромского государственного университета им. Н.А. Некрасова. 2012. Т. 18. № 2. С. 4-7.

3. Исаева О.Н. Использование инновационных технологий в обучении иностранному языку в рамках компетентностного подхода в системе непрерывного образования // Современные проблемы науки и образования. 2015. № 3. С. 495. 
4. Исаева О.Н. Формирование коммуникативной профессионально-ориентированной иноязычной компетентности студентов гуманитарного вуза // Современные проблемы науки и образования. 2015. № 2 .

URL: http://www.science-education.ru/122-18765

5. Костикова Л.П. Поликультурная толерантность как неотъемлемый компонент образования новой формации // Российский научный журнал. 2008. № 4(5). С. 88-95.

6. Костикова Л.П. Подготовка студентов гуманитарного вуза к межкультурному взаимодействию: монография. М.: МПСИ, 2010.216 с.

7. Концепция духовно-нравственного развития и воспитания личности гражданина России. М.: Просвещение, 2009. 24 с.

8. Постановление Правительства Российской Федерации от 4 октября 2000 г. N 751 2. Москва.

"О национальной доктрине образования в Российской Федерации".

9. Постановление Правительства Российской Федерации от 23 мая 2015 г. N 497 г. Москва.

«О Федеральной целевой программе развития образования на 2016-2020 годы».

10. Супрунова Л.Л. Поликультурное образование как важное направление модернизации школы в постиндустриальном обществе // Отечественная и зарубежная педагогика. 2014. № 3 (18). C. 81-88. 11. Федеральный закон от 29.12.2012 N 273-ФЗ (ред. от 13.07.2015) "Об образовании в Российской Федерации" (с изм. и доп., вступ. в силу с 24.07.2015).

12. Byram M. Teaching and assessing intercultural communicative competence. Clevedon:

Multilingual Matters, 1997.

(C) 2015, Быченкова Ю.В.

О формировании межкультурной компетенции у студентов вуза в системе непрерывного образования
(C) 2015, Bychenkova Yu.V.

Developing university students' intercultural competence in the system of life-learning education 